\title{
Text in context: a textual-linguistic approach to Amos 4: 7-8
}

\author{
Francisco Javier DEL BARCO DEL BARCO \\ CSIC, Madrid
}

\section{INTRODUCTION}

Ever since Wolfgang SCHNEIDER wrote his Grammatik des biblischen Hebräisch (München 1974) from a discourse-analysis perspective, many scholars have agreed that any study of the biblical Hebrew verb must be approached with a greater analytical breadth than just the sentence ${ }^{1}$. This analytical breadth has been identified as the text. The linguistic analysis of verb forms in context, i.e., the study of verbal syntax from a discourse-grammar perspective has been carried out by several scholars ${ }^{2}$, who focused mainly on the Biblical Hebrew prose.

* A part of this article was presented at the VIIth EAJS Congress, Amsterdam 2125 July 2002. This work is in the frame of the Research Project PB98-0851 Análisis Unificado de Textos Hebreos por Ordenador (AUTHOR).

1 In words of A. C. BowLING, "Another Brief Overview of the Hebrew Verb", JOTT 9 (1997) p. 49, «It is [...] impossible that interpretations based primarily upon morphology without significant consideration of discourse concerns could describe the meanings of the Hebrew verb».

${ }^{2}$ A few of the main works on this perspective are the following: F. I. ANDERSEN, The Sentence in Biblical Hebrew (The Hague 1974); R. LONGACRE, Joseph: a Story of Divine Providence. A Text Theoretical and Textlinguistic Analysis of Genesis 37 and 39-48 (Winona Lake 1989); Idem, «Discourse Perspective on the Hebrew Verb: Affirmation and Restatement», in Linguistics and Biblical Hebrew, ed. W. BODINE (Winona Lake 1992), pp. 177-189; Idem, «A Proposal for a Discourse-Modular Grammar of Biblical Hebrew», in Narrative and Comment: contributions presented to W. Schneider, ed. E. TALSTRA (Amsterdam 1995) pp. 99-103; A. NICCACCI, Sintassi del verbo ebraico nella prosa biblica classica (Jerusalem 1986); Idem, The Syntax of the Verb in Classical Hebrew Prose (Sheffield 1990); Idem, Lettura sintattica della prosa ebraico-biblica: principi e applicazioni (Jerusalem 1991); E. TALSTRA, «A

Sefarad 62 (2002) págs. 227-240

(c) CSIC

ISSN 0037-0894 
Robert LONGACRE ${ }^{3}$ identified different kinds of discourse depending on the speaker's linguistic intention, i.e., depending on the speaker's communication goals. This involves a different pattern of verb form usage in each type of discourse. According to Longacre's theory, the main discourse types found in prose are: narrative discourse, predictive discourse, procedural or instructional discourse, hortatory or persuasive discourse, expository discourse, and juridical discourse.

We will first see some of the kinds of discourse that can be found in prophetic texts, in order to understand the syntactic structures and the verb forms involved in each one of them, with examples taken directly from prophetic books. I will then analyse Amos 4:7-8 from a textlinguistic approach within the structure of the chapter in which it is inserted.

Such an analysis is needed because the set of verb forms used seems to be different from the rest of the verb forms used in the chapter. Differences between the two sets of verb forms used in Amos 4:7-8 are not usually noted in the translations, as we will see in many of the most important biblical translations to European languages.

\section{TYPES OF DISCOURSE}

In Longacre's own words, «narrative discourse tells a story about particular people and their actions and contingencies in past time» ${ }^{4}$. This means that narrative discourse is past oriented. A chain of wayyiqtol forms expresses the main line of communication, or foreground, while background actions would be expressed using qatal with no fronted element, and using qatal or yiqtol with a fronted element. In the first case, the syntactic structure is displayed as verb- $\mathrm{x}$, while in the second, as $\mathrm{x}$-verb, being $\mathrm{x}$ any nominal fronted element. When they are inserted in a wayyiqtol chain, the differences of use among qatal-x, $\mathrm{x}$-qatal, $\mathrm{x}$-yiqtol and participle clauses would be

Hierarchically Structured Data Base of Biblical Hebrew Texts», in Actes du 1er Colloque International Bible et Informatique: le texte. Louvaine la Neuve, septembre 1985 (Paris - Genève 1986) pp. 335-349; Idem, «Hebrew Syntax: Clause Types and Clause Hierarchy", in Studies in Hebrew and Aramaic Syntax presented to Professor J. Hoftijzer, eds. K. JONGELING et al. (Leiden 1991) pp. 180-193.

3 «Discourse Perspective».

${ }^{4}$ R. LONGACRE, «Discourse Perspective», p. 178. 
one of aspect: qatal-x expresses preparatory or resultant actions, $\mathrm{x}$ qatal expresses punctual background actions, and $x$-yiqtol and participle clauses express durative or repetitive actions.

Although not commonly used, narrative discourse is found here and there in prophecy. A good example is Amos 2:9-12, inserted in the oracle against Israel, the last of the oracles against the nations reported in chapters 1 and 2 of Amos. Here, God stresses Israel's past sins despite God's favors regarding Israel. The section is reported as the reason for Israel's future punishment that the prophet announces ${ }^{5}$ :

$$
\begin{aligned}
& { }_{9} \mathrm{~W}-\mathrm{x}^{1}-\mathrm{qatal}^{1}-\mathrm{x}^{3} \\
& \mathrm{p}-\mathrm{NC}^{3} \\
& \text { [p-]NC } \\
& \text { wayyiqtol }{ }^{1}-\mathrm{x}^{3} \\
& \text { [wayyiqtol }{ }^{1}-\mathrm{x}^{3} \\
& { }_{10} \mathrm{~W}-\mathrm{x}^{1}-\mathrm{qatal}^{1}-\mathrm{x}^{2} \\
& \text { wayyiqtol }{ }^{1}-\mathrm{x}^{2} \\
& \text { p-cons.inf.- } x \\
& { }_{11} \text { wayyiqtol }{ }^{1}-\mathrm{x}^{2} \text {. } \\
& \text { [wayyiqtol }{ }^{1}-\mathrm{x}^{2} \\
& \mathrm{p}-\mathrm{NC} \\
& \mathrm{F} \\
& { }_{12} \text { wayyiqtol }^{2}-\mathrm{x} \\
& \text { w-x-qatal }{ }^{2} \text {-inf. } \\
& \mathrm{N} \text {-yiqtol }{ }^{2}
\end{aligned}
$$

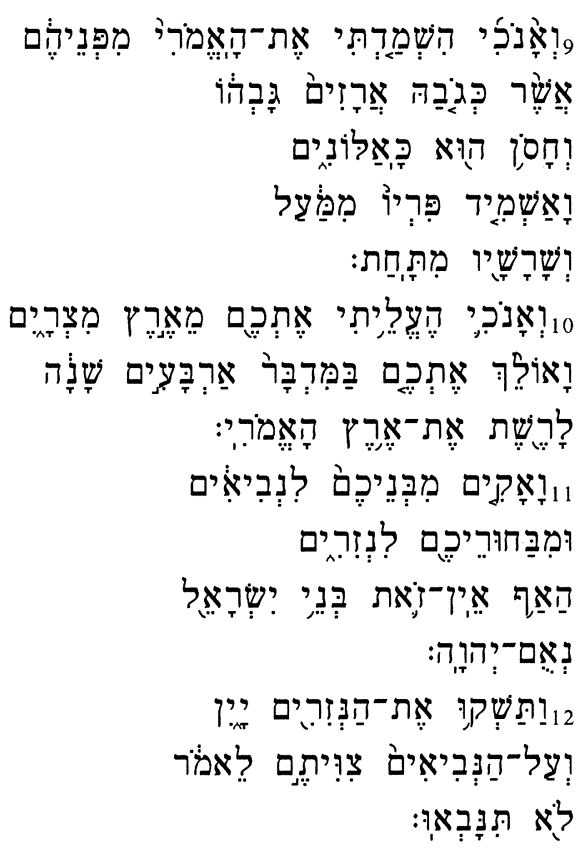

\footnotetext{
${ }^{5}$ The Hebrew text of the examples is from Biblia Hebraica Stuttgartensia [BHS] (Stuttgart 1977). Translations of the texts are from New Revised Standard Version of the Bible [NRSV] (Oxford 1989), unless otherwise indicated. In every example, the Hebrew text, in the right side, is accompanied by the syntactic structure of the clauses, in the left side. Abbreviations and symbols used are: $0=$ no element, $\mathrm{w}=$ waw, $\mathrm{p}=$ particle, $\mathrm{x}=$ nominal element, $\mathrm{NC}=$ nominal clause, $\mathrm{F}=$ (prophetic) formula, $\mathrm{N}$ = negative particle, $\mathrm{Q}=$ time reference, part. = participle, (cons.)inf. = (construct) infinitive, cohor. = cohortative. A number in superscript indicates the person of the verb or the person of the pronominal reference in a nominal element. Brackets indicate verb gapping.
} 
«(9) Yet I destroyed the Amorite before them, whose height was like the height of cedars, and who was as strong as oaks; I destroyed his fruit above, and his roots beneath. (10) Also I brought you up out of the land of Egypt, and led you forty years in the wilderness, to possess the land of the Amorite. (11) And I raised up some of your children to be prophets and some of your youths to be nazirites. Is it not indeed so, O people of Israel? says the Lord. (12) But you made the nazirites drink wine, and commanded the prophets, saying, 'You shall not prophesy.'»

Note the use of the chain of wayyiqtol as the main line of communication, and the use of qatal with a fronted element as backgrounded actions. Regarding time, verse 10 is not sequential to verse 9; on the contrary, the event reported in verse 10 is prior to that reported in verse 9:

(10) First event in time: «Also I brought you up out of the land of Egypt, and led you forty years in the wilderness, to possess the land of the Amorite».

(9) Second event in time: "Yet I destroyed the Amorite before them, whose height was like the height of cedars, and who was as strong as oaks; I destroyed his fruit above, and his roots beneath».

Predictive discourse is, as Longacre says, «a story told in advance of its happening» ${ }^{6}$. Predictive discourse is, therefore, future oriented. The main line of communication is made up using a weqatal chain, which expresses future events in the same way that a wayyiqtol chain expresses past events. When punctual actions or focus must be expressed, a yiqtol clause with a fronted element is used, and if the clause has a negative particle before the verb, a yiqtol clause is used again instead weqatal.

Regarding prophetic texts, predictive discourse is common. Prophets talk about future events completely convinced that they are going to happen. Thus, they described the future consequences of past sins and the future restoration of Israel's glory using predictive discourse. One of several examples of predictive discourse in preexilic Minor Prophets is Micah 5:9-14:

${ }^{6}$ R. LONGACRE, «Proposal», p. 100. 


\begin{tabular}{|c|c|}
\hline Sef 62:2 (2002) & TEXT IN CONTEXT: A TEXTUAL-LINGUISTIC ... \\
\hline${ }_{9}$ wehayah $-\mathrm{Q}$ & 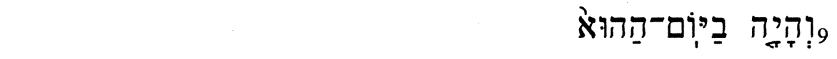 \\
\hline $\mathrm{F}$ & נְאֵם-יְהוָֹה \\
\hline weqatal ${ }^{1}-\mathrm{x}^{2}$ & 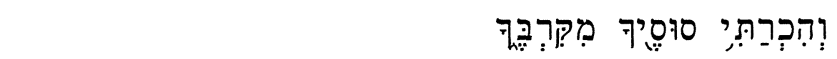 \\
\hline weqatal ${ }^{1}-\mathrm{x}^{2}$ & 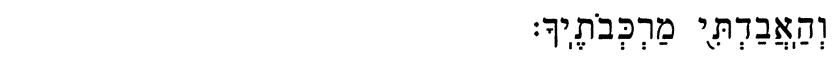 \\
\hline${ }_{10}$ weqatal ${ }^{1}-\mathrm{x}^{2}$ & 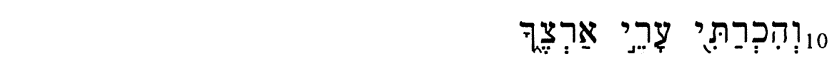 \\
\hline weqatal ${ }^{1}-x^{2}$ & 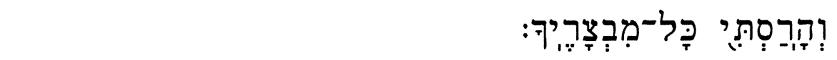 \\
\hline${ }_{11}$ weqatal ${ }^{1}-\mathrm{x}^{2}$ & 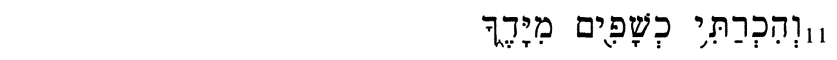 \\
\hline$w-x-N-y i q t o l^{3}-x^{2}$ & 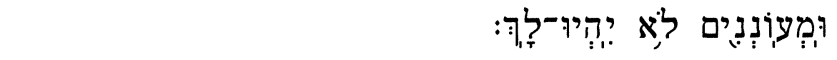 \\
\hline${ }_{12}$ weqatal ${ }^{1}-\mathrm{x}^{2}$ & 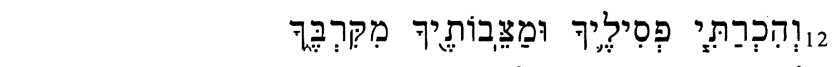 \\
\hline$w-N-y i q t^{2}-x^{2}$ & 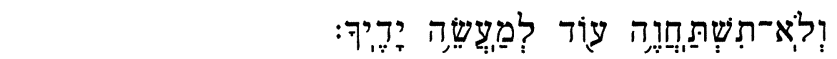 \\
\hline${ }_{13}$ weqatal $^{1}-\mathrm{x}^{2}$ & 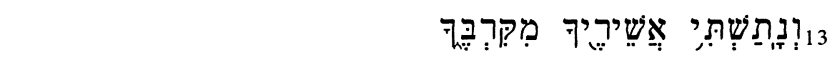 \\
\hline weqatal ${ }^{1}-x^{2}$ & 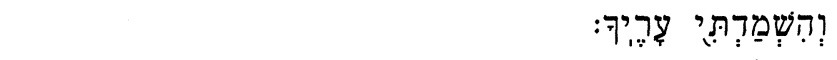 \\
\hline${ }_{14}$ weqatal ${ }^{1}-\mathrm{x}$ & 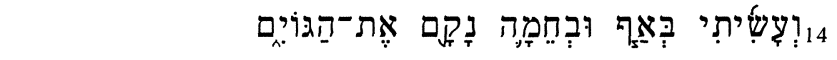 \\
\hline p-N-qatal ${ }^{3}$ & 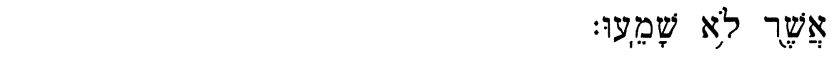 \\
\hline
\end{tabular}

«(9) In that day, says the Lord, I will cut off your horses from among you and will destroy your chariots; (10) and I will cut off the cities of your land and throw down all your strongholds; (11) and I will cut off sorceries from your hand and you shall have no more soothsayers; (12) and I will cut off your images and your pillars from among you, and you shall bow down no more to the work of your hands; (13) and I will uproot your sacred poles from among you and destroy your towns. (14) And in anger and wrath I will execute vengeance on the nations that did not obey.»

A construction with wehayah plus a future time reference is widely used to introduce predictive discourse in biblical prophecy. Note that all weqatal forms are in the $1^{\text {st }}$ p.s. but not the two yiqtol clauses. These two clauses are negative, so the use of a weqatal form would be impossible. The same can be said about the qatal clause, introduced by the relative 'ašer. As in this example, predictive discourse is future oriented.

Hortatory or persuasive discourse «is characteristic of the human situation in which one person tries to impose his or her will on another person» ${ }^{7}$. Thus imperatives, cohortatives and jussives make

${ }^{7}$ R. LONGACRE, «Discourse Perspective», p. 186. 
up this kind of discourse. Negative clauses with the particle 'al are used for negative commands. Typical of this kind of discourse is the so-called modal imperfect. Longacre explains that a persuasive discourse may show a mitigation of the imperatives which typically characterize it. This mitigation consists of using weqatal forms after one or two initial imperatives.

Hortatory or persuasive discourse is an important kind of discourse in prophetic texts. Direct address and commands from God, or the prophet, to the people are not uncommon. Hosea 14:2-4a is an example of hortatory discourse:

$$
\begin{aligned}
& { }_{2} 0-\text { qtol }^{2}-\mathrm{x}^{2} \\
& \text { p-qatal }{ }^{2}-x^{2} \\
& { }_{3} 0-\text { qtol }^{2}-\mathrm{x}^{2} \\
& \text { w-qtol }{ }^{2}-\mathrm{x} \\
& 0 \text {-qtol }{ }^{2}-x^{3} \\
& \mathrm{x} \text {-yiqtol }{ }^{2}-\mathrm{x} \\
& \text { w-qtol }{ }^{2}-\mathrm{x} \\
& \text { w-cohor. }{ }^{1}-\mathrm{x}^{1} \\
& { }_{4} \mathrm{x}-\mathrm{N} \text {-yiqtol }{ }^{3-1} \\
& \mathrm{x}-\mathrm{N} \text {-yiqtol }{ }^{1} \\
& \text { w-N-yiqtol }{ }^{1}-\mathrm{x}^{1}
\end{aligned}
$$

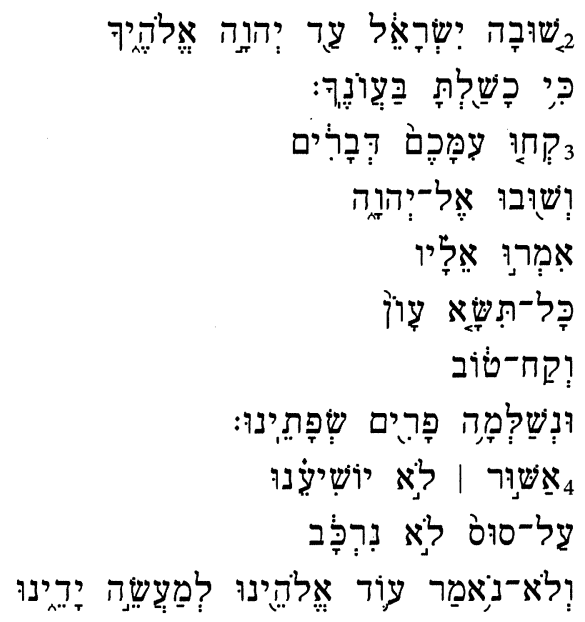

«(2) Return, O Israel, to the Lord your God, for you have stumbled because of your iniquity. (3) Take words with you and return to the Lord; say to him: -Take away all guilt; accept that which is good, and we will offer the fruit of our lips. (4) Assyria shall not save us; we will not ride upon horses; we will say no more 'Our God' to the work of our hands».

Imperatives make up the main line of communication, introducing direct speech. This direct speech is developed with an imperative, a cohortative, and some yiqtol forms. Note that $1^{\text {st }}$ and $2^{\text {nd }}$ personal references are widely used. This is typical in hortatory discourse. Note also that two of the yiqtol forms in verse 4 are in the $1^{\text {st }}$ person. Although they do not have the final - $h$ of the distinctive cohortative, they bear a volitive function equivalent to that of the distinctive cohortative. 
Another kind of discourse is the expository discourse. Here, nominal clauses and participle clauses bear the main line of communication. Some yiqtol or qatal clauses can be inserted in the discourse, but as a secondary explanation of some specific point of the exposition. Descriptions and static elements are basic in the expository discourse. Some texts belonging to this type of discourse can be found in chapter 2 of Habakkuk:
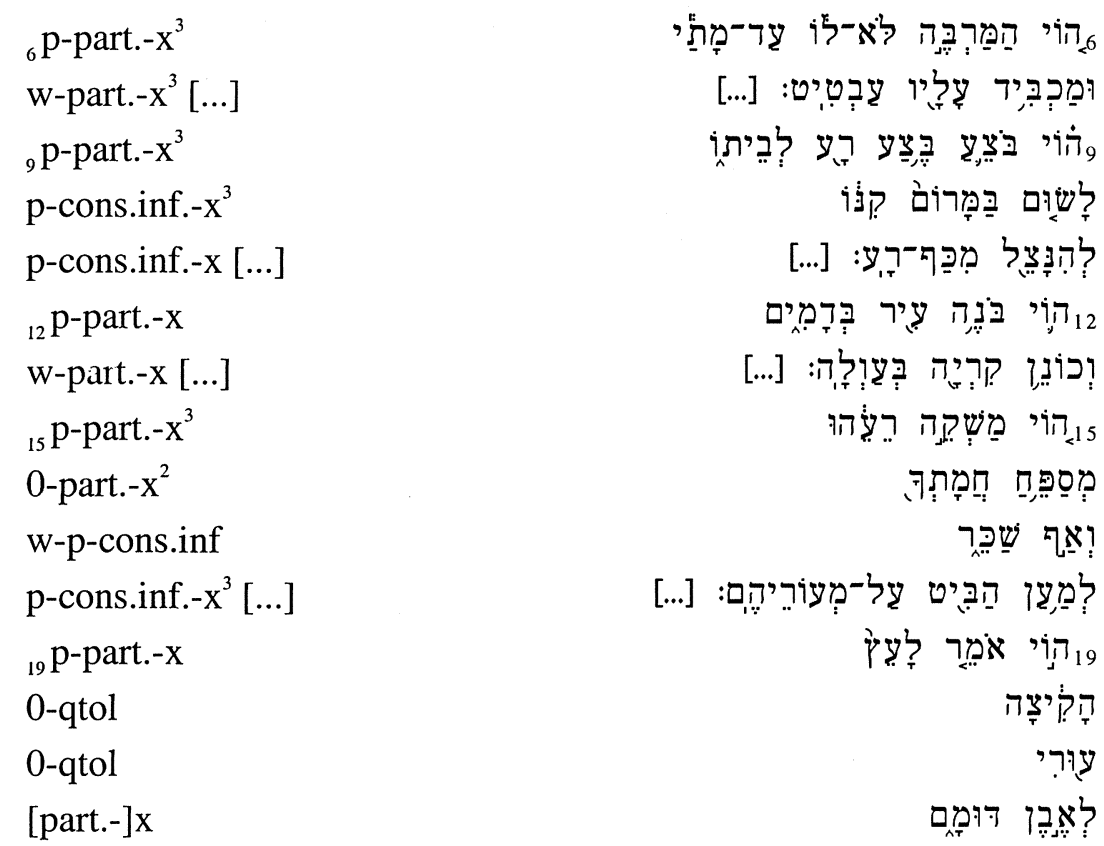

«(6) Alas for you who heap up what is not your own! How long will you load yourselves with goods taken in pledge? [...] (9) Alas for you who get evil gain for your houses, setting your nest on high to be safe from the reach of harm! [...] (12) Alas for you who build a town by bloodshed, and found a city of iniquity! [...] (15) Alas for you who make your neighbors drink, pouring out your wrath until they are drunk, in order to gaze on their nakedness! [...] (19) Alas for you who say to the wood, 'Wake up!' to silent stone, 'Rouse yourself!'»

The structure of this passage is based on the participle clauses which describe the people who are the object of the lamentation. The repetitive use of the particle hoy conveys the idea of lamentation. Thus, the structure of hôy plus participle constitutes an expository 
discourse in which other kinds of discourse are inserted. These insertions are represented with brackets in the text of the example. As the particle hoy is so important for this typical expository discourse in prophecy, I would prefer to call it lamentation discourse.

The examples shown above demonstrate that the specific purpose of communication is relevant to the syntactic structure of a text and plays a basic role in choosing verb forms that are to be used in the text. Among the different kinds of discourse that we have just reviewed, two of them involve the use of the so-called consecutive forms as the main line of communication: weqatal in predictive discourse and wayyiqtol in narrative discourse. This fact must be taken into account in the following analysis of the text in Amos 4:7-8.

\section{VERB FORMS IN AMOS 4:7-8}

As we have noted before, in this section of the book of Amos the set of verb forms used seems to be different from the rest of the verb forms used in the same chapter. Verses 7 and 8 constitute, altogether with verses $6,9,10$ and 11, a description of God's past punishments to Israel so that the israelites would regret their sins and turn back to God. But the israelites did not turn back to God, and this is proclaimed by the prophet at the end of each reported punishment

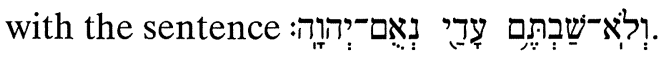

Each one of verses 6, 9, 10, 11 express one different past punishment suffered by the israelites:

$$
\begin{aligned}
& { }_{6} \mathrm{~W}-\mathrm{x}^{1}-\mathrm{qatal}^{1}-\mathrm{x}^{2}
\end{aligned}
$$

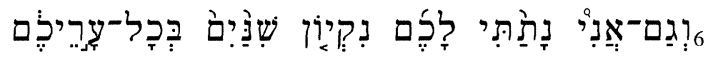

$$
\begin{aligned}
& w-\left[x^{1}-q a t a l^{1}-\right] x^{2}
\end{aligned}
$$

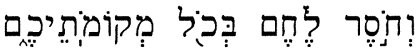

$$
\begin{aligned}
& \text { w-N-qatal }{ }^{2}-\mathrm{x}^{1}
\end{aligned}
$$

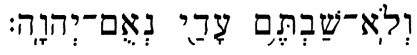

«(6) I gave you cleanness of teeth in all your cities, and lack of bread in all your places, yet you did not return to me, says the Lord».
${ }_{9} 0-$ qatal $^{1}-\mathrm{x}^{2}$
$0-x^{2}-$ yiqtol $^{3}-\mathrm{x}$

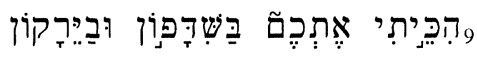

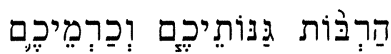
w-N-qatal ${ }^{2}-\mathrm{x}^{1}$

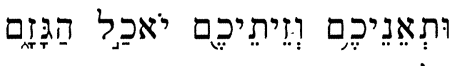

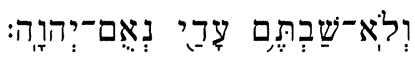


«(9) I struck you with blight and mildew; I laid waste your gardens and your vineyards; the locust devoured your fig trees and your olive trees; yet you did not return to me, says the Lord».

$$
\begin{aligned}
& { }_{10}^{0-\text { qatal }^{1}-\mathrm{x}^{2}} \\
& 0 \text {-qatal } \\
& { }^{1}-\mathrm{x}^{2} \\
& \text { wayyiqtol }^{1}-\mathrm{x}^{2} \\
& \text { w-N-qatal } \\
&
\end{aligned}
$$

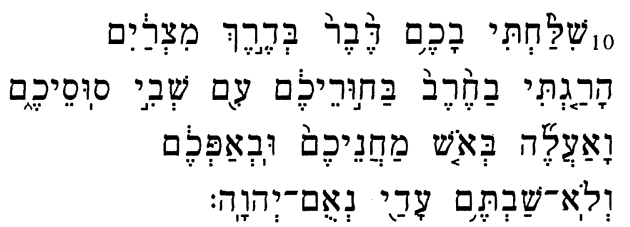

«(10) I sent among you a pestilence after the manner of Egypt; I killed your young men with the sword; I carried away your horses; and I made the stench of your camp go up into your nostrils; yet you did not return to me, says the Lord».

$$
\begin{aligned}
& { }_{11} 0-\text { qatal }^{1}-x^{2} \\
& \text { wayyiqtol }{ }^{2}-\mathrm{x} \\
& \text { w-N-qatal }{ }^{2}-\mathrm{x}^{1}
\end{aligned}
$$

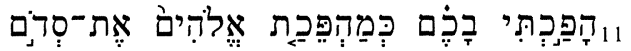

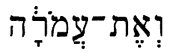

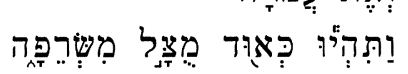

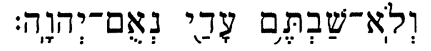

«(11) I overthrew some of you, as when God overthrew Sodom and Gomorrah, and you were like a brand snatched from the fire; yet you did not return to me, says the Lord».

In terms of the verb forms used, it is clear that these verses are past oriented in time. Qatal in the first position of its clause is used not only in the prophet's proclamation at the end of each one of the punishments reported, but also at the beginning of verses 9,10 and 11. In verses 10 and 11 , we find a wayyiqtol clause after qatal in the first position of its clause. This tense transition ( 0 -qatal $\rightarrow$ wayyiqtol) is characteristic of narrative discourse, as we have seen when explaining the set of verb forms used in narrative discourse ${ }^{8}$. Verses 6 and 9 are too short to develop the first qatal clause into a narrative

${ }^{8}$ A. NICCACCI, Sintassi del verbo ebraico nella prosa biblica classica (Jerusalem 1986) pp. 22-32 points out the importance of tense transitions between wayyiqtol and qatal clauses, and the specific function of a qatal clause as a preceding structure to a wayyiqtol chain. 
wayyiqtol clause, but the use of the same kind of qatal clauses than afterwards in verses 10 and 11, indicates that the type of discourse is the same, i.e., narrative discourse. The use of a yiqtol clause in verse 9 does not seem to change this temporal perspective, because the yiqtol clause is parallel to the preceding qatal clause, and the difference in the use of the verb form chosen seems to be related to an aspectual distinction rather than a change in the time perspective?

In contrast to what we have just explained for verses 6 and 9-11, in verses 7-8 we find something different:

${ }_{\text {}}$ w-p-x

weqatal $^{1}-$ qatal $^{1}-\mathrm{x}^{2}$
w-x-N-yiqtol
0-x-yiqtol
w-x-yiqtol
p-N-yiqtol
${ }^{3}-\mathrm{x}^{3}$
${ }_{\text {weqatal }}^{3}-\mathrm{x}$
p-inf. cons.-x
w-N-yiqtol
w-N-qatal
- $\mathrm{x}^{1}$

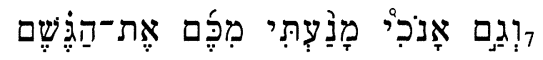

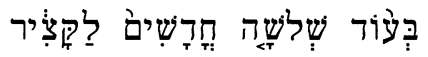

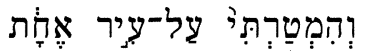

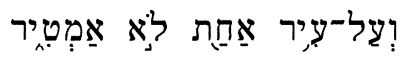

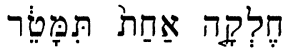

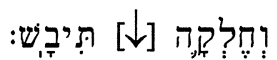

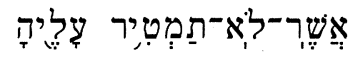

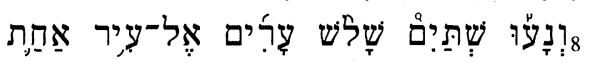

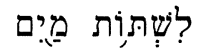

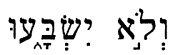

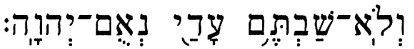

The first and last clauses are, as in the other report of punishments, qatal clauses. The last clause is, again, the repetition of God's reproach to the israelites because they did not turn back to him. But the middle section shows a completely different use for a set of verb forms. Instead of qatal and wayyiqtol clauses, we find yiqtol and weqatal clauses, i.e., the typical set of verb forms used in predictive discourse. Note that all yiqtol clauses have a fronted element, or the negative particle ; this means that yiqtol clauses are inserted here

\footnotetext{
${ }^{9}$ On the use of qatal-yiqtol sequences in Hebrew verse, see A. BERLIN, The Dynamics of Biblical Parallelism (Indianapolis 1992) pp. 35-36; M. HELD, «The yqtlqtl (qtl-yqtl) Sequence of Identical Verbs in Biblical Hebrew and in Ugaritic», in Studies and Essays in Honour of Abraham A. Neuman, eds. M. BEN HoRIN et al. (Leiden 1962) pp. 281-290; W. G. E. WAtson, Classical Hebrew Poetry: A Guide to its Techniques (Sheffield 1984) p. 279.
} 
because weqatal clauses cannot be used, as they do not accept any fronted element before the verb form.

With such verb forms, it is very difficult to maintain a past oriented time to this particular section. The form is that of a predictive discourse, as we have described it before, but a future oriented time for verses 7-8 does not seem to fit with the rest of the chapter, which is describing God's past punishments to Israel.

\section{THE TRANSLATIONS}

How do biblical versions in European languages translate Amos 4:7-8? Even though these two verses present a use of a set of verb forms different than the rest of the chapter, no translation seems to have noticed this particular feature.

We will present here six biblical versions in four different languages: two in English and Spanish, and one in French and German.

The King James (KJ) English version is the traditional, classical and most accepted literal translation of the Bible into English. Here, Amos 4:7-8 is translated as follows:

«(7) And also I have withholden the rain from you, when there were yet three months to the harvest: and I caused it to rain upon one city, and caused it not to rain upon another city: one piece was rained upon, and the piece whereupon it rained not withered; (8) so two or three cities wandered unto one city, to drink water; but they were not satisfied: yet have ye not returned unto me, saith the Lord».

The New Revised Standard Version (NRSV) of the Bible is an upto-date translation in modern English. Here we find as follows:

«(7) And I also withheld the rain from you when there were still three months to the harvest; I would send rain on one city, and send no rain on another city; one field would be rained upon, and the field on which it did not rain withered; (8) so two or three towns wandered to one town to drink water, and were not satisfied; yet you did not return to me, says the Lord».

In both versions, it is as if verses 7-8 were a narrative discourse identical to the other narrative sections in the same chapter. But the set of verb forms is different, as we have noted before. Even NRSV maintains the past time orientation, in spite of the fact that it is a recent translation. 
The Cantera-Iglesias Spanish version of the Bible (Sagrada Biblia $^{10}$ ) is a recent and literal translation of the Bible, accepted nowadays as the closest version to the Hebrew and Greek texts. It offers the following translation of the same text:

«(7) Además, Yo os negué la lluvia estando aún a tres meses de la recolección; luego hice llover sobre una ciudad, y sobre otra ciudad no lloví [sic]; un campo alcanzó lluvia, y otro campo, sobre el cual no llovió, se secó; (8) dos y tres ciudades vagabundearon hasta otra ciudad para beber agua, mas no se saciaron; pero no os habéis convertido a Mí -oráculo de Yahveh».

Past time orientation is clear in this version, as is in the less literal but more literary translation of L. Alonso Schökel and J. Mateos (Nueva Biblia Española ${ }^{11}$ ):

«(7) Aunque yo os retuve la lluvia tres meses antes de la siega, hice llover en un pueblo sí y en otro no, en una parcela llovió, otra sin lluvia se secó; (8) de dos o tres pueblos iban a otro para beber agua, y no se hartaban, no os convertísteis a mí, -oráculo del Señor-».

Alonso Schökel understands these two verses as a concessive sentence («aunque...»), but he maintains a past time orientation, according to the rest of the chapter.

The French Bible de Jérusalem offers the following translation of Amos 4:7-8:

«(7) Aussi, moi je vous ai refusé la pluie, juste trois mois avant la moisson; j'ai fait pleuvoir sur une ville et sur une autre ville je ne faisais pas pleuvoir; un champ recevait de la pluie, et un champ, faute de pluie, se desséchait; (8) deux, trois villes allaient en titubant vers une autre pour boire de l'eau sans pouvoir se désaltérer; et vous n'êtes pas revenus à moi ! Oracle de Yahvé».

This French version also maintains a past time orientation for verses 7-8. The use of yiqtol clauses is understood to be a way to express the imperfective aspect, and this is translated into French by imperfects («faisais», «recevait», «desséchait»).

\footnotetext{
${ }^{10}$ F. CANTERA and M. Iglesias, Sagrada Biblia (Madrid 1979).

${ }^{11}$ L. Alonso SchöKEl and J. MATEOS, Nueva Biblia Española (Madrid 1975).
} 
Luther's German version of the Bible does not vary the past time orientation in these verses. He translates as follows:

«(7) Auch habe ich euch den Regen vorenthalten, als noch drei Monate waren bis zur Ernte, und ich ließ regnen über eine Stadt, und auf die andere Stadt ließ ich nicht regnen, ein Acker wurde beregnet, und der andere Acker, der nicht beregnet wurde, verdorrte. (8) Und es zogen zwei, drei Städte zu einer Stadt, um Wasser zu trinken, und konnten nicht genug finden; dennoch bekehrt ihr euch nicht zu mir, spricht der Herr».

Luther's version is not, however, directly translated from Hebrew, but from Latin Vulgata, translated from Hebrew by Jerome. But even the Vulgata presents a past time orientation for verses 7-8:

«(7) Ego quoque prohibui a vobis imbrem, cum adhuc tres menses superessent usque ad mensem; et plui super unam civitatem et super alteram civitatem non plui: pars una compluta est, et pars, super quam non plui, aruit. (\&) Tunc fugiebant duae, tres civitates ad unam civitatem, ut biberent aquarn, et non satiabantur; sed non redistis ad me, dicit Dominus».

\section{CONCLUSION}

The reason why Vulgata and the rest of translations do not pay attention to the fact that verb forms in verses 7-8 are not narrative forms, is not known to me, but an analysis from the discourse grammar and context concerns seems to claim a new interpretation of Amos 4:7-8. Such a new perspective will probably arise problems of textual criticism, because verses 7-8 do not maintain the narrative set of verb forms used in the rest of the chapter.

The translations presented above show the general and accepted interpretation of chapter 4 of Amos, in which the whole chapter is translated as a past time sequence. In my opinion this is a coherent solution regarding the semantic aspect of the chapter, but there is no reason to translate verses 7-8 as a past oriented section if we focus on the set of verb forms used. These two verses probably do not belong to the original text of the chapter, but this is a matter of textual criticism which I am not going to deal with in this article. The important thing here is that if one focuses on the use of verb forms in verses 7-8, according to the kinds of discourse described above, the section must be interpreted as a predictive discourse with a future time orientation. 


\section{RESUMEN}

En este artículo se presenta un análisis de Amos 4:7-8 a partir de los presupuestos de la lingüística textual. La forma del texto se analizará tomando en cuenta la estructura del capítulo en el que se halla inserto. Este análisis resulta necesario porque el grupo de formas verbales utilizado en la sección propuesta no parece ser el mismo que el del resto del capítulo. Mientras el capítulo en su conjunto es un discurso narrativo estructurado en torno a wayyiqtol, Amos 4:7-8 parece responder al esquema del discurso predictivo desarrollado a partir de weqatal. Un análisis textual se hace necesario porque las traducciones bíblicas no parecen hacerse eco del cambio en el uso de las formas verbales. Además de este análisis, se trata también de la función específica de algunos tipos de discurso.

PALABRAS CLAVE: Lingüística textual, poesía profética, lengua hebrea, Biblia, Amos.

\section{SUMMARY}

This article will study Amos 4:7-8 from a textlinguistic approach: the form of this section will be analyzed within the structure of the chapter in which it is inserted. Such an analysis is needed because the set of verb forms used seems to be different from the rest of verb forms used in the chapter. While the whole chapter tends to be structured as a brief chain of narrative passages with wayyiqtol, the structure of Amos 4:7-8 seems to be a predictive section-developed through weqatal-inserted or pasted in the middle of the chapter. Translations usually do not note the difference between the set of verb forms used. A textlinguistic analysis of Amos 4:7-8 will show that the kind of discourse used here is different from the one used in the rest of the chapter, and, therefore, this difference should be reflected in the translation. The specific function of some discourse types is also discussed.

KEYwORDS: Textlinguistics, Prophetic Poetry, Hebrew Language, Bible, Amos. 